\title{
CONFLICTING THEORIES OF CORPORATE . INCOME TAXATION ${ }^{2}$
}

\author{
GrRhard COLM*
}

\section{The Problem of Corporate Incone Taxation}

The income tax is the last step in the long development of taxes away from the ad rem basis, especially from land taxes, to a tax basis which reflects as perfectly as possible individual ability to pay. The important role played by income taxes in modern tax systems seems to indicate the triumph of this "ideal tax" over the older, less perfect forms of taxation. ${ }^{2}$ In countries in which the income tax had already been highly developed a further increase in income tax revenue was made possible by increasing the income tax on corporations (e.g., Germany, Great Britain, Italy). Does this fact indicate that the individual income tax is approaching its administrative or political limits, at least in certain countries, and that further substantial expansion of revenues can be expected only from an increase in the corporate.income tax? What is the significance of a rising share of the corporate tax in the total yield cf income taxes? Is the application of the income tax to corporations 2 logieal supplement to the individual income tax and does it participate in all the merits of this "ideal" tax? Or does the appiication of the income tax to corporations in reality indicate a reversal of development, a trend turning back to another sort of ad rem taxation-but in the disguise of the meritorious income tax? Is the corporate income tax an income tax at all, or is it just another form of business taxation? If so, is a. business tax based on corporate profits the most rational method of taxing business?

- Dr. Rer. Pol., 1931, Freiburg University, Germany. Professor of Bconomics at the Graduate Faculty of Political and Social Science, New School for Social Research, New York, now on leave of absence as Fiseal Expert in the U. S. Department of Commerce. Member of the Commitze on Federal Tasation of Corporations of the Nanonal Tax Association. Formerly professor at Riel University, Germany. Co-author of Economic Consequences of Recent Anterican Tax Policy, Socal Reseaxch, Supplement I, 2938.

In this article I shall draw heavily on the Final Report of the Committee of the National Tax Association on Federal Taxation of Corporations, presented at the National Tax Conference bedd $x$ San Franciseo, California, October 16-19, :939. Professor Robert M. Haig of Columbia University wras chairman of the committee. When speaking of "the committec" of "the majority" or "the minority" I r.fer :o the work of this commitree. The repart is cited hereinafier as Final Repopr. -

In recent years the share of income taxes in the total tax revenue declined in sereral countries, partiy because of the infuence of the depression on this very sensitive type of taxation, pardy because of the development of other tax sourees, such as sales taxes, automobile taxes, payroll taxes, ex. cf. Colm, Significant Tax Legisiation is Foreign Countries, NAt. TAx Ass', Proceinivas, 1938, p. 526.

"The accuracy of calling corporate profits "income" an be questioned. 
The answer to these questions may be in part supplied by a review of the various thecries and rationales of corporate income taxes.

\section{Corporate Income Taxes as a Fors of Business Taxation}

It is easy to justify corporate income taxes by reference to the "cynical" rule of taxation, which stresses their high fiscal productivity. The fact that the necessary revenue cannot be Jerived from ability-to-pay taxes in a strict sense is the strongest argument for taxes on business." Corporations have substantial funds at their disposal, and their bookkeeping can be more easily supervised than that of farmers or storekeepers. From one income tax return of a corporation more money can be obtained on an average than from one tax return of an individual.

However, corporate income taxes are usually defended on the ground of the benefit principle and not of the ability-to-pay principle. ${ }^{5}$ The question comes up especially in the discussion of whether a corporate income tax should have a graduated rate or a flat rate. Prevailing opinion is that the various arguments proposed for a progressive individual income tax cannot be applied to corporations. ${ }^{\circ}$ The arguments of equal sacrifice, maximum collective utility or the redistribution of income are rooted in the fact that an individual must meet his most urgent noeds for food, clothing and shelter first. If he has a higher income he can satisfy his demand for luxury consumption or for economic security, which from the point of view of the community are supposed to be less urgent than the fundamental needs. Now it cannot be said that each additional dollar of corporate profits has 2 declining utility value from the viewpoint of the corporation or of the community at large. In this respect the analogy between the legal personality and the natural personality has little validity. This leads theorists who believe that no tax principle other than ability-to-pay is valid, to recommend the scrapping of corporate income taxes as such, and their retention only as a supplement to the collection of individual income taxes.7

Limited liability, legal and operative continuity of the company (for instance in the case of the death of the owner or a partner), easy transfer of ownership, diffused sources of financing, the possibility of intercorporate affiliations-these are some of the corporation advantages created by law and as such regarded as a justification for special taxes on corporations. Furthermore, the corporation offers certain tax advantages which will be discussed later. Yet it is difficult to judge how great these advantages are and how heavy a corporate tax can be defended on this ground. Proof that present tax rates do not outwcigh the advantages of the corporate form

\footnotetext{
'Within the limits of this article no proof can be given for this statement, on which the reasoning of this article rests.

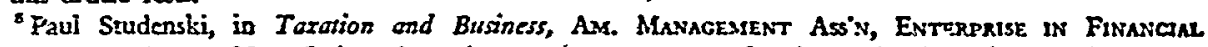
Mnsacemest Series, No. 58 (3939), maks a very strong case for the application of the ability-to-pay principle to corporations. Very much depends on how ability-to-pay is being defined.

e Finar Repost, 50-51.

"See, for instanse, Stmoxs, Pepsonal lincose Taxsties (1938). This was also the theory behind Presiden: Roosevelits recommendation for the 1956 Revenue Act. See Hearings before she Commirter on Whays and Mems en Revenue Aitt 1936, 74th Cong., 2d Sess. (1936) $x_{0}$ ff.
} 
can be seen in the fact that many businesses prefer incorporation, although they could equally well be conducted as partnerships. But the recent increase in corporate tax rates in Germany up to 35 and $40 \%$ of profits resulted in the transformation of many corporations into partnerships. 8 Many types of businesses, however, have no real choice as to incorporation; it is a necessity for them.

The corporate income tax has been further justified by the services which the government renders to business in general. Paramount among these is the system of laws which is the foundation of modern business and their legal enforcement through the courts. The skill and efficiency of labor which is an essential prerequisite of modern industry is at least partly due to public education. The government takes care of a variety of social costs resulting from business operations; it takes care especially of the unemployed, preserving their ability to work for any future demand of business. But all businesses, whether incorporated or not, benefit from these services. It is true that in most lines of production the nation's business is carried on in corporate form and it would do no great harm if the smaller proprietorships and partnerships really should enjoy a certain tax advantage. Nevertheless, this problem may become quite important if the corporate income tax rates should be further increased and if the tax advantages of the corporate form should be reduced or eliminated in the future.

The benefit principle has been invoked also to justify a progressive tax rate on the grounds that the benefits derived from the corporate form are supposed to increase progressively with the size of the corporation. ${ }^{\circ}$ It has been said ${ }^{\mathbf{1 0}}$ that larger corporations have (a) comparatively stronger bargaining position; (b) advantages of a nation-wide market; (c) advantage in making use of patents and research programs; (d) often quasi-monopolistic position; (e) advantages in financing. ${ }^{11}$ Such arguments justify a graduation of corporate taxes, but by no means such a graduation of rates as is justified for individuals on the basis of the ability-to-pay principle.

The implications of the benefit principle can be shown with respect to one technical detail of corporate income taxes. From the point of view of ability to pay there would be no justification for including dividends received by a corporation from another corporation in the taxable profits. These dividends were taxed as profits of the distributing corporation and their inclusion among taxable profits of the receiving corporation leads to a clear case of double taxation. If, however, the benefit principle in invoked, it can be said that the right of corporations not only

\footnotetext{
- About half the corporations were dissolved. However, this abandonment of the corporate form was due only in part to the effects of tax rates, as new legislation forbade the corporate form to sinall enterprises.

- Strictly speaking this principle would lead to rates prostressive with corporate size as measured for instance by the size of capital assets. A strong case can be made for a graduated excess profits tax. This will not be discussed here because a separate article of this Quarterly will be devoted to the subject. For a few remarks on it, see part IV, infra p. 288.

${ }^{10}$ Hearings before the Senate Finance Committee on Revenue Act 1935, 74th Cong., xst Sess. (1935) $216,21 \%$.

${ }^{12}$ Comparc also Final Report, 51, 0. 72.
} 
to operate their own business but to acquire stocks of other corporations is a special privilege justifying a tax which need not be paid by corporations making no use of this privilege. This argument could be used for instance in defense of the present law which treats $15 \%$ of dividends received as taxable income. It could not be used to defend a prohibitive tax, which may be justified only on grounds of economic rather than fiscal policy. ${ }^{12}$

The benefit principle justifies a tax on corporatuons, a moderate graduation of rates according to size, and a moderate tax on intercorporate affiliation. But does it lead to the conclusion that an income tax is the best method of taxing corporations according to benefits received? It has been said ${ }^{13}$ that the government is, so to speak, a silent partner in all business and as such should receive its share in all profits. A similar argument was officially proposed in Germany when the corporate income taxes were raised to 35 and $40 \%$. It was said that government expenditures assure a high and steady level of profits and that it is therefore justifiable for a large proportion of these profits to be:absorbed by the government.

It has been argued, on the other hand, ${ }^{14}$ that the government gives its services to all business whether profitable or not. A business pays for labor or for raw materials irrespective of whether profits are made or not; likewise business should contribute to government because government is supposed to render its services in good times and bad.

- Both ways of reasoning have their partial justification, and probably the solution is that the government should tax corporate profits and in addition business as such on some basis other than profit. The Committee expressed the opinion that a special corporation fee should be levied on the basis of capitalization or some other such factor, and that in addition, corporations as well as individual proprietorships and partnerships should be taxed on the basis of either net profit or some cost factor (preferably "value added by manufacture") or both. If both levies are considered as two forms of business taxes, the Committee suggests the assignment of the net profit tax to the federal government, the cost-factor tax to the states. ${ }^{16}$ Such a cost-tax on business should replace existing sales and property imposts on business which, from the point of view of equity, are probably the least rational form of taxation.10 The corporate income tax can more, easily be administered as a federal tax, avoiding the whole problem of the apportionment of the tax according to the location of establishments ino various states. It is easier; however, to levy taxes on cost factors like sales or "value added" on a state basis because turnover and costs are usually ascertainable for each establishment even if it belongs to a larger interstate concern and the plant cannot be moved as easily as can the domicile of a corporation.

12 See part IV, infra p. 288.

${ }^{20}$ See Final Report, pt. II, p. 30, ff. The metaphor was employed by the late T. S. Adams.

16 Ibid.

${ }^{28}$ See Final. Report, 50, 51.

${ }^{20} \mathrm{~A}$ tax on business property appears justified only to the extent that local expenditures for fire and police protection, means of communication, etc., can be attributed to business. 
The corporate income tax fluctuates widely with the business cycle while a costfactor tax is more stable. This confirms the suitability of the former tax as a federal levy because the federal government can meet a deficit more easily in depressions than can states and local governments.

The corporate income tax, it can be concluded, has a definite place in the system of business taxation. The present need for government revenue surpasses economic, administrative and political limits set by the practicability of collecting taxes from individuals. Therefore, taxes on business are a fiscal necessity. Taxes on business are justified also by the benefit principle because government services today form an essential factor of production. Compared with other business taxes, the corporate income tax may not be the closest possible approximation to the benefit principle, since government services are rendered to profitable and non-profitable businesses alike. From this point of view business taxes levied on some other basis than profits may appear preferable. But it must not be forgotten that the benefit principle is not the only standard for evaluating taxes. From the point of view of the ability-. to-pay principle the corporate income tax is certainly inferior to the individual income tax but it corresponds more to this principle than do other business taxes.

Cost-factor taxes on business are either shifted forward and become a burden on consumers or shifted backward and lead primarily to wages lower than would exist otherwise. In so far they are regressive taxes. This process of shifting creates frictions, especially in periods of depressed business conditions. Corporate income taxes, on the other hand, tend to curtail dividend distribution or else to lower the equity value of stockholdings. But in the short run, at least, they do not cause changes in the price-cost structure. ${ }^{17}$ Since most stocks are held by people of the wealthier classes, it can be assumed that this tax, besides corresponding, although crudely, to the benefit principle does satisfy the ability-to-pay principle better than do other business taxes. ${ }^{18}$ Yet from neither aspect is it an "ideal" tax, and it is justified only as a supplement to business-cost taxes, on the one hand, and to individual income taxes, on the other.

\section{Corporate Income Taxes Supplementing Individual Income Taxes}

Corporate income taxes have often been used as an administrative device for collecting individual income taxes at the source and as such allowed as a tax credit or rebate in the individual income tax returns. If the tax exempt limits are low, as, for instance, in Great Britain and Germany, and if stockholdings of people in the lower income brackets are infrequent, the administrative advantages of collection at the source are probably greater than the costs and trouble involved in rebating. If, however, the tax exempt limit is relatively high and stockholdings widely dis-

${ }^{27} \mathrm{It}$ is not intended to discuss here the problems of shifting and incidence of corporate income taxes. A detailed analysis probably would resslt in a slight qualification of the statement in the text, which may be accepted, nevertheless, as 2 rule of thumb.

${ }^{10}$ A graduated corporate income tax could be defended on this ground only if it could be shown that in general wealthier people tend to invest in larger corporations. No evidence exists to prove such a tendency. 
tributed, as is the case in the United States, then this method is less advantageous. A second limitation is the fact that this method is primarily applicable to 2 flat rate income tax and is not easily adaptable for collecting progressive individual income taxes at the source.

Taxation at the source may function in two ways. In Germany it is a method of tax collection and no more. The tax is deducted from dividend and interest distributions to individuals. In Great Britain (as also in earlier years in the United States) corporations pay the tax on all their profits and the individual stockholders receive tax credit on their dividend income. This latter method results not merely in easier collection of individual income taxes but in addition it amounts to a tax on undistributed profits of at present $35 \%$ in Great Britain. Such an approach therefore seems to solve one of the greatest problems of individual income taxation. If a stockholder owns stock in a corporation which distributes only a part of its profits, the equity value of the stock increases. This accretion of "economic power" is not taxed unless the income tax law provides for a capital gains tax and the stockholder realizes the gain by selling his stock. The British method solves this problem as far as the normal tax is concerned but not with respect to the progressive surtaxes.

An undistributed profits tax was introduced in the Federal Revenue Act of 1936 . This tax met enormous resistance; it was refined but at the same time emasculated in the Revenue Act of $193^{8}$ and repealed in the 1939 Act. Yet the repeal does not mean that the problem is settled. It is significant that the Committee of the National Tax Association stated, "By its action in 1939 allowing the undistributed profits tax to lapse, Congress merely retreated from this problem without solving it."19 Undistributed profits of corporations constitute a significant element in the base of the personal income tax because, in the fundamental economic sense, they are savings, and savings from a part of the concept of taxable income that appeals to the conscience of the American people as the best measure of relative ability-to-pay taxes. ... . Fundamentally ... the savings of a corporation are the savings of the individuals who own the corporation. If savings in general are taxed as income, there should be no exemption of the savings of certain individuals whose investments take the legal form of shares in corporations that do not distribute their carnings promptly and completely.... To exempt them would not only be grossly unfair to those using other forms of saving but would also provide a broad avenue for cvasion. . . ."20 "Otherwise this particular form of saving is unjustly subsidized as compared with other forms of saving. ..."21 The minority of the Committee did not deny these fundamental statements but preferred a solution similar to the British method of taxing undistributed profits. "These members of the Committee recognize that the failure to bring all corporate earnings to account for personal income tax involves favorable treatment for corporate savings but are not disturbed by this fact." ${ }^{22}$ The

${ }^{10}$ FINAL REPORT, 49.

21 Id. at IO.
20 Id. at 9.

II. at 29. 
undistributed profits tax has been called a "penalty" tax on corporations. There is no justification for this expression. The failure to tax undistributed profits is a premium upon or a subsidy to one specific type of savings which is not granted to other types. ${ }^{23}$ Such a premium cannot be defended on the ground of equity in taxation but must be examined as to whether or not it is warranted by reasons of economic policy. ${ }^{24}$

The Committee reviewed the various existing devices for taxing undistributed profits. The majority did not regard the special tax on "improper accumulations" of profits ${ }^{25}$ as a solution of the problem because a stockholder pays no tax on undistributed profits no matter what the reason for the corporation's retaining the profit. An unfortunate feature of the undistributed profits tax of 1936 was that it confused two problems which are not essentially interrelated, namely the actual cash disbursement of profits, and second, the problem of imposing a tax equivalent to the individual income taxes on undistributed profits. The majority of the committee preferred tax devices which would affect the actual cash dispositions of corporations as little as possible. Such devices are-

I. Taxation of corporations on the same basis as partnerships. The majority of the committee was of the opinion that this method might necessitate a constitutional amendment and is essentially applicable only to corporations of which the stocks are not widely dispersed.

2. Imposition of a prohibitive tax to compel fuil distribution of profits. The majority recommended this method only if distribution in other forms than cash (treasury stock, stock"dividends) is legally possible, ie., if stock dividends are taxable as individual income.

3. Employment of information certificates of non-distributed earnings on which the individual stockholder will be taxed in his own income tax returns. This method, too, might meet legal obstacles and technical difficulties in the case of corporations with complicated financial structures. A similar but optional device is the consent dividend of the Revenue Act of 1938.28

In case these methods should not be possible the majority recommended a compensatory tax on undistributed profits imposed directly on the corporation. This tax should produce approximately the same yield as would taxation of all profits in the hand of the individual stockholders. Although such a tax. would lead to greater equality than exists without it, and although it would saseguard the aggregate yield to the Treasury, it "will work an injustice to the poor shareholder and grant a subsidy to the rich shareholder. However, the inequities involved are much less important than the inequities that exist in a situation in which the distribution of corporate savings is not enforced and no compensatory tax is levied." ${ }^{27}$

\footnotetext{
${ }^{22}$ It is significant that this fact is acknowledged by the majority of the committee as well as by the niinority.

26 See part IV, infra, p. 288

16. 528 .

${ }^{25}$ INT. REv. CODE $\$ 102$.

"Final Report, 28.
} 
All members of the majority recommended some combination of these various methods. There was a difference in opinion with respect to the legal and technical difficulties implied in the various methods and therefore the preference for the respective methods varied. One member suggested the desirability of federal incorporation and the establishment of two distinct types of corporations. The first type would be limited to the resources of local financing and taxed by the partnership method. The second type would have the privilege of utilizing the national capital market and would be subject to an undistributed profits tax as well as to a corporate privilege tax, which would be higher than the one on corporations limited to local financing and subject to the partnership method of taxation. Business would have the option of selecting whichever type of corporate charter best fitted the nature and scope of the business, but the type of charter chosen would determine the tax method to be applied. ${ }^{28}$-An undistributed profits tax would therefore be applied only to corporations which have easy access to the capital market. If the tax should lead to increased cash distribution it would not affect the smaller corporations for which the 1936 Act probably created a special hardship.

\section{Corporate Income Taxes as a Technique of Economic Contror}

The greatest differences in opinion arise with respect to the use of corporate income taxes as a means of economic control. Within the space available only a brief survey of the conflicting theories on this problem can be presented.

There are first those who still stick to the classical principle of the "neutrality" of taxation. According to this view taxes should influence cconomic processes as little as possible. But as the level of tax rates rises it becomes more and more obvious that there are no. neutral taxes, if there ever were. If taxes inevitably affect the economic process, then it becomes desirable to direct tax policy in such fashion that its economic effects accord with the objectives of rational policy. The principle of neutrality of taxation is being transformed into the principle of consistency.

Corporate income taxes influence the organization of business in several ways. In the past there was a prevalent tax advantage for corporations as against partnerships or individual proprietorships (because of the absence of a tax on undistributed profits). As mentioned before, a high rate of corporate taxes may outweigh this advantage and act as an incentive to transform corporations into partnerships. The corporate tax has been successfully used to this end in Germany.

Tax considerations play a big role, furthermore, in deciding the structure of corporations. Intercorporate stockholdings have been used as a means for controlling corporations without necessarily involving full financial responsibility for the controlled corporations. Consolidated balance sheets and tax exemption for intercorporate dividends permit free use of this device. Full taxation of intercorporate dividends at high rates would lead to the dissolution of some of such affliations, and the transformation of others into outright mergers. This, likewise, is a question

${ }^{23}$ Id. at 28, n. $40,2 d$ par. 
transcending the fiscal aspect and necessitating a very important decision in the ficld of economic policy.29

Corporate income taxes have been recommended as a means of monopoly control and of windfall taxation. If corporate profits taxes are progressive with respect to the profitability of the invested capital, they will absorb at least a part of the profits resulting from imperfect competition. ${ }^{30}$

In discussing the problem of undistributed profits it has already been stated that high individual income taxes encourage the flow of savings into stocks as long as undistributed profits remain tax exempt. A premium on this form of saving may be defended as desirable as long as that tax system in other respects favors investment in bonds rather than stocks. It would be more logical, however, to recommend that the premiums for investment in bonds (for example, tax exemption of government securities) should be removed.

Corporate income taxes have a substantial influence on business financing. Since interest payments can be deducted as costs it is advantageous to finance corporations by bonds rather than by the issue of stock. In a few foreign countries profits before deduction of interest are used as a basis for corporate taxation in order to impose an equal burden on corporations financed by bonds and those financed by equity. In some states (for instance, Pennsylvania) a compensatory tax on obligations is levied.

The undistributed profits tax of 1936 was introduced mainly with the intention of bringing about more equal individual income taxation. Arguments of economic policy were suggested in addition. It was said, for instance: (a) that the distribution of funds through the hands of stockholders and the institutions of the capital market assures a more rational use of the available capital supply than does the retention of profits; (b) that the control of corporate financing by institutions like the Securities and Exchange Commission could be made more effective if a greater pereentage of financing were done through capital issues rather than through self-financing; (c) that undistributed profits were often used for investment in stocks of other corporations and thereby enhanced the concentration of economic power, ${ }^{31}$ assuming that the same investment in the stock of other corporations would not have been made had the transaction had to be financed by a capital issue; and (d) that distribution of profits as dividends would increase consumption because a certain percentage of dividends received would not be reinvested. This latter argument was proposed by those who saw in oversaving one of the fundamental maladjustments of the modern economy. $\$ 2$

I personally believe that much truth lies in the theory of oversaving. Yet the enforcement of enlarged distributions in the winter of 1936 occurred at a time when

"I do not deal with this important problem because a special article in this symposium will be devoted to it See Miller, The Taxation of Intercompany Iricome, infra p. $30 \mathrm{x}$.

${ }^{20}$ Cf. Buchler, The Taxation of Corporate Excess Profits in Peace and War Times, infra, at p. 299.

"See the President's message to Congress, April 29, 1938, 83 Cong. Rec. 5995 (1938).

${ }^{32}$ In the Dutch corporate income tax retained profits are left tax exempt in order to stimulate capital accumulation. 
this policy probably had an undesirable effect. ${ }^{33}$ An incentive for increased cash distribution should be handled with care, to preserve its flexibility. Taxation of undistributed profits as recommended by the Committee would not necessarily force distribution of cash dividends. If an incentive to increase the cash distribution is held desirable for economic reasons a tax premium for cash distribution (as distinguished from distribution of information certificates, stock dividends or other non-cash forms) could be provided within such a system of taxation. If the premium were suspended in an economic situation in which retention of corporate profits appeared desirable, the taxation of undistributed profits would not thereby be eliminated.

The excess profits tax has also been recommended as a means of dispersing a part of profits which might otherwise be accumulated as idle reserves. This argument has special validity in a situation in which corporations enjoying extraordinary favorable market conditions make high profits (for instance, war profits), despite generally uncertain business conditions which are not very encouraging for new investments.

Idle funds may result not only from retained profits but also-and probably to a larger extent-from depreciation charges not used for actual repairs and replacements. It might be worth while to investigate whether a tax premium for actual replacements as distinct from depreciation would be at all feasible.

It has been often suggested that a tax incentive be introduced for corporations which increase employment. ${ }^{34}$ In pre-Hitler Germany an experiment of this sort was carried out by Chancellor von Papen. This plan failed.35 In general it can be assumed that the great burden of overhead costs in itself acts as a forceful incentive for full employment. If corporations nevertheless dismiss workers and leave factories idle, it is due to adverse market conditions which are beyond the control of individual enterprises. It seems very doubtful that their policy can be changed by addifig a penalty in the form of a tax credit to the automatic punishment imposed on idleness by overhead costs. It seems a more effective recovery device to absorb idle funds by government taxes or government borrowing and convert them into active purchasing power through government outlays.

With these considerations of incentive taxation, however, we enter the realm of the most controversial issues. So far little experience is available for weighing the various proposals made in this field. A combination of willingness to explore the possibilities and of enough scepticism to preserve us from expecting inientive taxation to be a panacea probably is the appropriate attitude with respect to this problem.

\footnotetext{
${ }^{22}$ Sce Colm and Lehmann, Economic Consequences of Recent American Tax Policy (2937) 4 Soctar Resensch, Supp. 1.

"See, for instance, Hazelett, Incentive Taxamon, A Key to Security (3d ed., 1939).

${ }^{28}$ See Colm, Why the Papen Plan Failed (1934) I Social. Research, reprinted in Survey of Experiences in Profit Sharing and Possibilities of Incentive Taxation, Report of the Subcommitice on Finance, U. S. Senate, pursuant S. Res: 215, SeN. Rep. 610, 76th Cong., ist Sess. (1939) 276, ff.
} 